\title{
Effect of grain maturity stage on the quality of sorghum BRS-610 silages
}

[Efeito do estádio de maturação dos grãos na qualidade das silagens do sorgo BRS-610]

\author{
W.G. Faria Júnior ${ }^{1}$, L.C. Gonçalves ${ }^{1}$, G.O. Ribeiro Júnior ${ }^{1}$, W.T.V. Carvalho ${ }^{2}$, R.M. Maurício ${ }^{3}$, \\ J.A.S. Rodrigues ${ }^{4}$, W.G. Faria ${ }^{2}$, E.O.S. Saliba ${ }^{2}$, N.M. Rodriguez ${ }^{2}$, A.L.C.C. Borges ${ }^{2}$ \\ ${ }^{1}$ Escola de Veterinária - Universidade Federal de Minas Gerais - UFMG \\ Rua Antônio Carlos, 6627 - Pampulha \\ 30123-970 - Belo Horizonte, MG \\ ${ }^{2}$ Instituto Federal de Educação - Ciência e Tecnologia - Campus Barbacena - Barbacena, MG \\ ${ }^{3}$ Universidade Federal de São João Del-Rei - São João Del Rei, MG \\ ${ }^{4}$ EMBRAPA: Centro Nacional de Pesquisa Milho e Sorgo - Sete Lagoas, MG
}

\begin{abstract}
The quality of sorghum BRS-610 silages in seven stages of grain maturity, between the milky and dry stage, for determination of the ideal moment of ensilage was evaluated. The silos were open after 56 days of fermentation. The values for dry matter of silages increased from 199 to $473 \mathrm{~g} / \mathrm{kg}$ or from 19.9 to $47.3 \%$, with the advance of stage maturity of grains. As for the quality of fermentation, the silages may be classified as excellent quality in every stage of maturity. The lower values of neutral detergent fiber, $539 \mathrm{~g} / \mathrm{kg}$ or $53.9 \%$, and acid detergent fiber, $307 \mathrm{~g} / \mathrm{kg}$ or $30.7 \%$, were observed between the milky/dough to dough/dent stages. Regression analysis indicated an increase in values of lignin - 0.3 unit por stage and reduction in values of in vitro dry matter digestibility - -2.5 units por stage - with the advance of the grain's stage maturity. The ensilage of sorghum BRS-610 between the milky/dough and dough stage ensure very good fermentation and nutritive value of silage.
\end{abstract}

Keywords: nutritive value, classification, digestibility, harvest moment, sorghum silage

\section{RESUMO}

Avaliou-se a qualidade das silagens do sorgo BRS-610 em sete estádios de maturação dos grãos, entre o estádio leitoso a estádio seco, para determinar o momento ideal de ensilagem. Os silos foram abertos após 56 dias de fermentação. Os teores de matéria seca das silagens aumentaram de 199 para 473g/kg, ou de 19,9 para 47,3\%, com o avanço do estádio de maturação dos grãos. Quanto à qualidade de fermentação, as silagens foram classificadas como de excelente qualidade para todos os estádios de maturação. Os baixos valores de fibra detergente neutro, $539 \mathrm{~g} / \mathrm{kg}$ ou 53,9\%, e fibra detergente ácido, $307 \mathrm{~g} / \mathrm{kg}$ ou $30,7 \%$, foram observados entre os estádios leitoso/pastoso a pastoso/farináceo. A análise de regressão indicou aumento nos teores de lignina, 0,35 unidades por estádio, e redução nos valores de digestibilidade in vitro da matéria seca, -2,50 unidades por estádio, com o avanço do estádio de maturação dos grãos. A ensilagem do sorgo BRS-610 entre os estádios de grãos leitoso/pastoso a pastoso, garante excelente fermentação e bom valor nutricional da silagem.

Palavras-chave: silagem de sorgo, classificação, digestibilidade, momento colheita, valor nutritivo

\section{INTRODUCTION}

Ensilage is one of the best forms of forage conservation used in Brazil, ensuring feed for ruminants during the dry season. According to
McDonald et al. (1991), adequate forage preservation through the ensilage process depends on the production of lactic acid and on maintaining low $\mathrm{pH}$ values, as well as on low concentrations of ammoniacal nitrogen and acetic and butyric acids. The literature suggests

Recebido em 17 de março de 2010

Aceito em 27 de junho de 2011

E-mail: wilsonvet2002@gmail.com 
that good quality sorghum ensilage may be obtained with amounts of dry matter varying from 20\% to 35\% (Borges et al., 1997; Bernardino et al., 1997; Brito et al., 2000; Rocha Jr. et al, 2000; Pires et al., 2006).

The maturity stage may influence the chemical composition and alter conservation quality as well as the nutritional value of sorghum silages. Sorghum hybrids present divergent behavior which is mainly associated to the difference in proportions between the plant's structural components. Differences in the amounts of neutral detergent fiber, acid detergent fiber, lignin and in vitro dry matter digestibility were not observed by Araújo et al. (2007) for hybrids of double purpose harvested between the milky and dry stages. On the other hand, different behavior between the hybrids for these variables was observed by Pires et al. (2006) while evaluating eight stages of maturity (from flowering to dry grain) of double purpose hybrids.

BRS-160 Sorghum presents dry stalk, without tannin, and was obtained from the cross between CMSXS 232A and CMSXS 234R sorghums, from the sorghum breeding program at Embrapa Corn and Sorghum. BRS-160 stands out for its resistance to pests and diseases, good adaptability to the cerrado due to its tolerance to acid soils and drought, good resistance to lodging, which favors mechanical harvesting, with minimal losses in the field (Rodrigues et al., 2004). However, there is little information available concerning the quality of this hybrid's silage between the plant's stages of maturity. This is primordial for determining the adequate interval or maturity stage for ensilage of this hybrid, which will ensure good conservation of the silage forage and good nutritional value.

The objective of this study was to evaluate the quality of sorghum BRS-610 (Sorghum bicolor (L.) Moench) silages, in seven stages of maturity, from the milky stage to the dry grain stage.

\section{MATERIALS AND METHODS}

Sorghum BRS-610 was cultivated, harvested and ensiled at the National Research Center of Corn and Sorghum - Embrapa, in Sete Lagoas, MG, during the agricultural year of $2005 / 2006$. The material was planted in 32 beds ( $7 \mathrm{~m}$ vs $3.5 \mathrm{~m}$ ), with row spacing of $70 \mathrm{~cm}$. Cutting was done at soil level in the 2 central rows, discarding one meter on the extremities of each bed. The sorghum was planted on November $26^{\text {th }}, 2005$, with milky stages being reached on March $2^{\text {nd }}$, 2006, 96 days after planting. Silage was produced in a seven-day interval starting on this date and corresponded to the following stages of grain maturity: milky, milky/dough, dough, dough/dent, dent, hard and dry.

The material was chopped, sampled homogeneously and stored in PVC laboratory silos $(10 \mathrm{~cm}$ diameter $\mathrm{x} 40 \mathrm{~cm}$ height). The silos were opened on the $56^{\text {th }}$ day of fermentation.

The ensilage was removed from the silos and homogenized. Part of the material was pressed and the silage extract obtained was immediately evaluated for $\mathrm{pH}$ and ammoniacal nitrogen relative to total nitrogen $\left(\mathrm{N}-\mathrm{NH}_{3} / \mathrm{NT}\right)$ by distillation with calcium chloride and magnesium oxide (Official..., 2000). Part of the silage extract $(10 \mathrm{~mL})$ was frozen with metaphosphoric acid at a 5:1 dilution for posterior determination of organic acids in gas chromatography (chromatograph Shimadzu GC-17 ${ }^{\mathrm{a}}$ ) using a Nukol capillary column (10m in length and $1 / 4$ inch in diameter) packed with Cromosorb 101 (80-100 mesh) as the stationary phase.

The other part was weighed and pre-dried in an air-forced oven at $55^{\circ} \mathrm{C}$ for 72 hours for the determination of pre-dried matter. The pre-dried samples were milled at $1 \mathrm{~mm}$. Dry matter (DM) content was determined in an oven at $105^{\circ} \mathrm{C}$ and crude protein (CP) was determined by the Kjeldhal method (Official..., 2000). Neutral detergent fiber (NDF), acid detergent fiber (ADF) and lignin were determined by solubilization of cellulose with sulphuric acid ( $72 \% \mathrm{p} / \mathrm{p})$, through the sequential method of Van Soest et al. (1991), using thermo-stable $\alpha$ amilase (Termamyl 120L), without sodium sulfite, according to Mertens, (2002), with the Fiber analyzer $\mathrm{ANKOM}^{220}$. The in vitro dry matter digestibility (IVDMD), was obtained according to Holden (1999) for the utilization of rumen simulator Daisy ${ }^{I I}$ ANKOM $^{\circledR}$. The inoculo was obtained from a fistulated bovine maintained on a diet of Tifton grass 85 hay, ad libidum and a daily $3 \mathrm{~kg}$ of commercial concentrate (20\% CP), fed at $8 \mathrm{am}$ and $5 \mathrm{pm}$. The ruminal liquid was 
Effect of grain maturity...

collected before feeding, from the liquid:solid interface region in the ruminal environment.

The experimental design used was completely randomized with four beds per stage of maturity. The data was submitted to a variance analysis. The averages were compared by the Scott-Knott grouping method, at $5 \%$ probability. The response curves as a function of maturity were obtained by regression analysis, using the $\mathrm{F}$ test. The SAEG statistical package was used (Sistema..., 2007). Silage fermentation quality was determined according to the point criteria proposed by Tomich et al. (2003) (Table 1).

Table 1. Classification of silages according to the point criteria $\mathrm{pH}$ values associated with dry matter content in the silage

\begin{tabular}{|c|c|c|c|c|c|}
\hline \multicolumn{6}{|c|}{ Dry matter content (\%) } \\
\hline \multirow{7}{*}{$\mathrm{pH}$ values } & $<20$ & $20-30$ & $30-40$ & $>40$ & Point \\
\hline & $<4.0$ & $<4.2$ & $<4.4$ & $<4.6$ & 25 \\
\hline & $>4.0-4.2$ & $>4.2-4.4$ & $>4.4-4.6$ & $>4.6-4.8$ & 20 \\
\hline & $>4.2-4.4$ & $>4.4-4.6$ & $>4.6-4.8$ & $>4.8-5.0$ & 15 \\
\hline & $>4.4-4.6$ & $>4.6-4.8$ & $>4.8-5.0$ & $>5.0-5.2$ & 10 \\
\hline & $>4.6-4.8$ & $>4.8-5.0$ & $>5.0-5.2$ & $>5.2-5.4$ & 5 \\
\hline & $>4.8$ & $>5.0$ & $>5.2$ & $>5.4$ & 0 \\
\hline \multicolumn{2}{|c|}{$\mathrm{N}-\mathrm{NH}_{3} / \mathrm{NT}(\%)$} & \multicolumn{2}{|c|}{ Butyric acid (\%MS) } & \multicolumn{2}{|c|}{ Acetic acid (\%MS) } \\
\hline Value & Point & Value & Point & Value & Point \\
\hline$<10.0$ & 25 & $0.0-0.1$ & 50 & $<2.5$ & 0 \\
\hline $10.0-13.0$ & 20 & $>0.1-0.3$ & 40 & $>2.5-4.0$ & -5 \\
\hline$>13.0-17.0$ & 15 & $>0.3-0.5$ & 30 & $>4.0-5.5$ & -10 \\
\hline$>17.0-21.0$ & 10 & $>0.5-0.7$ & 20 & $>5.5-7.0$ & -15 \\
\hline$>21.0-25.0$ & 5 & $>0.7-0.9$ & 10 & $>7.0-8.5$ & -20 \\
\hline$>25.0$ & 0 & $>0.9$ & 0 & $>8.5$ & -25 \\
\hline \multicolumn{6}{|c|}{ Final Classification } \\
\hline Final Score & $\begin{array}{c}\text { Excellent } \\
90-100\end{array}$ & $\begin{array}{l}\text { Good } \\
70-89\end{array}$ & $\begin{array}{c}\text { Fair } \\
50-69\end{array}$ & $\begin{array}{c}\text { Bad } \\
30-49\end{array}$ & $\begin{array}{c}\text { Very bad } \\
<30\end{array}$ \\
\hline
\end{tabular}

Compiled from Tomich et al. (2003)

\section{RESULTS AND DISCUSSION}

The values for silage DM increased with the advancement of the grain maturity stage, however, the evaluation of the averages has shown significant differences only in the transition from dough to dough/dent stages and between the hard and dry stages (Table 2).
Regression analysis indicated linear increases $(\mathrm{P}<0.01)$ of 3.7 units in the amounts of DM in the silage between the stages, which were in one week intervals (Figure 1). 
Faria Júnior et al.

Table 2. Fermentative parameters for the silage of sorghum BRS-610 produced in seven stages of grain maturity

\begin{tabular}{|c|c|c|c|c|c|c|c|c|}
\hline \multirow[b]{2}{*}{ Variable } & \multicolumn{7}{|c|}{ Grain maturity stage } & \multirow[b]{2}{*}{ CV $(\%$} \\
\hline & Milky & Milky/Dough & Dough & Dough/Dent & Dent & Hard & Dry & \\
\hline DM (\%) & $19.86 \mathrm{c}$ & $24.15 c$ & $24.48 c$ & $27.59 \mathrm{~b}$ & $30.52 b$ & $32.37 b$ & $47.31 \mathrm{a}$ & 11.98 \\
\hline $\mathrm{pH}$ & $3.7 \mathrm{~d}$ & $3.8 \mathrm{~d}$ & $3.9 \mathrm{c}$ & $4.0 \mathrm{c}$ & $4.1 \mathrm{~b}$ & $4.2 \mathrm{~b}$ & $4.5 a$ & 2.90 \\
\hline $\begin{array}{l}\mathrm{N}- \\
\mathrm{NH}_{3} / \mathrm{NT}^{1}\end{array}$ & $1.25 \mathrm{~d}$ & $1.44 \mathrm{~d}$ & $2.26 \mathrm{c}$ & $2.54 \mathrm{c}$ & $4.26 \mathrm{~b}$ & $4.42 \mathrm{~b}$ & $5.99 a$ & 22.30 \\
\hline $\begin{array}{l}\text { Lactic } \\
\text { acid }^{2}\end{array}$ & $10.48 \mathrm{a}$ & $8.66 \mathrm{a}$ & $7.64 \mathrm{a}$ & 7.92a & $7.56 \mathrm{a}$ & $5.16 \mathrm{~b}$ & $3.80 \mathrm{~b}$ & 21.26 \\
\hline $\begin{array}{l}\text { Acetic } \\
\text { acid }^{2}\end{array}$ & $2.72 \mathrm{a}$ & $1.90 \mathrm{a}$ & $2.39 a$ & $2.72 \mathrm{a}$ & $2.65 a$ & $1.95 \mathrm{a}$ & $0.89 \mathrm{~b}$ & 26.97 \\
\hline $\begin{array}{l}\text { Butyric } \\
\text { acid }^{2}\end{array}$ & $0.03 c$ & $0.03 c$ & $0.03 c$ & $0.02 \mathrm{c}$ & $0.07 \mathrm{a}$ & $0.04 \mathrm{~b}$ & $0.12 \mathrm{a}$ & 38.16 \\
\hline
\end{tabular}

Means within a row without a common letter differ $(\mathrm{P}<0.05)$ by Scott-Knott test. ${ }^{1} \%$ of ammoniacal nitrogen in relation to total nitrogen; ${ }^{2} \%$ dry matter.

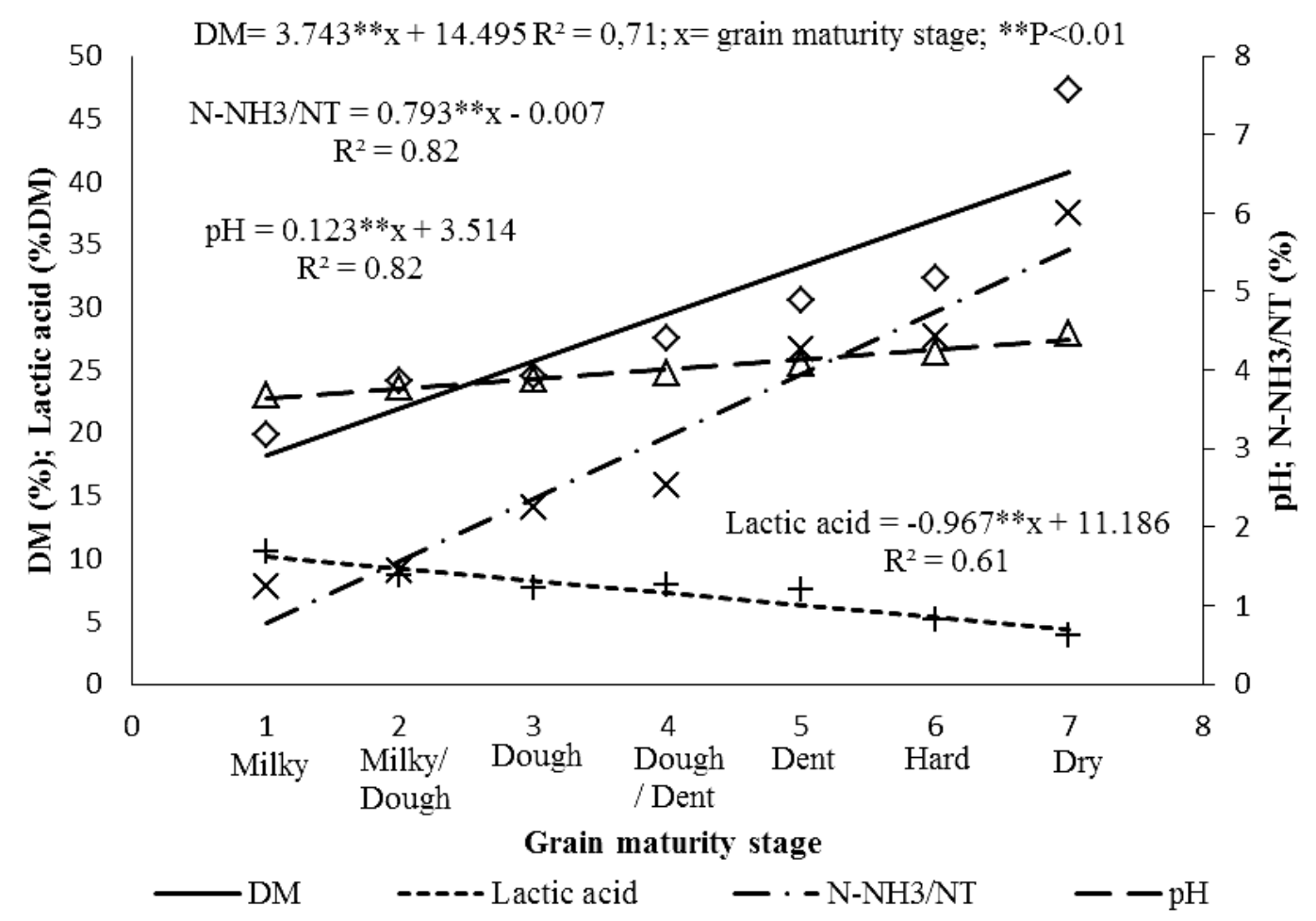

Figure 1. Tendency curves for the estimated values of dry matter, lactic acid, $\mathrm{N}-\mathrm{NH}_{3} / \mathrm{NT}$ and $\mathrm{pH}$ for silage of sorghum BRS-610 in seven stages of grain maturity. 1-milky; 2-milky/dough; 3-dough; 4dough/dent; 5-dent; 6-hard; 7-dry; with one week intervals between stages, starting with flowering (0).

Araújo et al. (2007) observed DM increases ranging from 4.0 to 5.4 units between stages of maturity of double purpose sorghum silages with the advancement of the maturity stage. Molina et al. (2002) and Pires et al. (2006) also observed an increase in DM amounts with the advancement of the stage of maturity, associated to an increase in the participation of the sorghum plant's panicle. The amounts of DM necessary to ensure good conservation of the silage must be evaluated along with the $\mathrm{pH}$ values, because even silages with lower amounts of DM can be well preserved as long as they present low $\mathrm{pH}$ values, as suggested by Tomich et al. (2003). 
Values for the silages $\mathrm{pH}$ increased with the advancement of grain maturity stage (Table 2), however, the values obtained seem to have guaranteed the good conservation of the silages. Increases in $\mathrm{pH}$ values with maturity were observed by Pires et al. (2006) and Araújo et al. (2007). According to these authors the elevation in the amounts of DM are responsible for the elevation in the $\mathrm{pH}$ values, presenting high correlations $(r=0.82$ and $r=0.86$, respectively, $\mathrm{P}<0.01$ ) among the variables.

Values for $\mathrm{N}-\mathrm{NH}_{3} / \mathrm{NT}$ were very low (Table 2), but increased linearly in the order of 0.8 units per stage of maturity (Figure 1). Pires et al. (2006) observed higher values for $\mathrm{N}-\mathrm{NH}_{3} / \mathrm{NT}(6.0 \%$ a $7.8 \%$ ), which then reduced from flowering to the stage of dry grain, due to the elevation of the amount of DM with maturity. On the other hand, alterations in the levels of $\mathrm{N}-\mathrm{NH}_{3} / \mathrm{NT}$ with maturity were not observed by Araújo et al. (2007). These authors observed average levels of $\mathrm{N}-\mathrm{NH}_{3} / \mathrm{NT}$ of $5.5 \% ; 5.4 \%$ and $7.1 \%$ for the sorghum hybrids BR700, BR701 and Massa-3, respectively, in PVC experimental silos.

Variations for this parameter are a reflex of the falling speed of $\mathrm{pH}$, which inhibits the activity of proteolytic enzymes from the plant, as well as from the proteolytic microorganisms present in the silage. The elevation in the DM levels, $\mathrm{pH}$ and the reduction of lactic acid levels may be responsible for the elevation in the levels of $\mathrm{N}$ $\mathrm{NH}_{3} / \mathrm{NT}$, due to some degree of proteolysis by the plant enzymes in the more advanced stages of maturity. Very good quality silages present levels of $\mathrm{N}-\mathrm{NH}_{3} / \mathrm{NT}$ between $0-10 \%$. Therefore, the silage from hybrid BRS-610 may be considered of very high quality for all stages of maturity. This suggests that the proteolysis which took place during the fermentative process within the silo was reduced, thus preserving the quality of the ensiled forage.

The organic acids most commonly determined in the silages were lactic, acetic and butyric acids. Values for lactic acid were not different until the dent stage, decreasing in aftermost stages (Table 2). However, regression analysis indicated a linear fall of 0.9 units at each stage of maturity. This behavior agrees with results from Moisio and Heikonen (1994) and Araújo et al. (2007) who reported reductions in lactic acid content as the levels of DM in the silage increased. Inferior values of lactic acid were observed by Rocha Jr. et al. (2000) (3.2\% to $8.5 \%)$. Based on this parameter the silage produced until the hard grain stage can be considered of very high quality (levels of lactic acid above $5.0 \%$ ), according to Borges et al. (1997).

The values for acetic acid were not different up to the dent grain stage, however, values higher than $2.5 \%$ were observed in the milky, milky/dent and dent stages (Table 2). Borges et al. (1997) and Araújo et al. (2007) found correlation of $r=0.79$ and $r=0.63(\mathrm{P}<0.01)$, respectively, between acetic and lactic acids. These authors suggest that in these conditions, great part of the acetate is derived from heterofermentative fermentations. In this study there was high and positive correlation $(\mathrm{P}<0.01)$ between lactic and acetic acids $(r=0.74)$. Due to the low values of ammoniacal nitrogen and butyric acid, it is possible that a situation similar to that described by these authors may have occurred.

The values for butyric acid were constant and low until the dough/dent stage, however, for successive stages, significant increases were observed (Table 2). Although there were variations in butyric acid content the values were low, which suggests good forage conservation, and may imply that there was a limitation in the development of microorganisms from the genera Clostridium sp. Borges et al. (1997), Rocha Jr. et al. (2000) and Araújo et al. (2007) produced good quality silages with butyric acid values ranging from $0 \%$ to $0.3 \%$.

As to the quality of fermentation, the silages may be classified as excellent for all the stages of maturity, reflecting the aptitude of the hybrid for conservation in the form of silage (Table 3).

The levels of CP presented little variation with the stage of maturity, with lower values $(\mathrm{P}<0.05)$ between the dough/dent and dent stages. The advancement of the maturity stage did not result in CP level reductions in the silage. On the other hand, reductions in the values of $\mathrm{CP}$ with the advancement of maturity were observed by Pires et al. (2006) and Araújo et al. (2007). Regression analysis did not indicate a model that was adequate to the response, showing low $\mathrm{R}^{2}$ values and no significance. 
Faria Júnior et al.

Table 3. Scores and classification for the silage of sorghum BRS-610 produced in seven stages of grain maturity $^{1}$

\begin{tabular}{|c|c|c|c|c|c|c|c|}
\hline \multicolumn{8}{|c|}{ grain maturity stage } \\
\hline Variable & Milky & Milky/Dough & Dough & Dough/Dent & Dent & Hard & Dry \\
\hline $\mathrm{MS} / \mathrm{pH}$ & 25 & 25 & 25 & 25 & 25 & 25 & 25 \\
\hline $\mathrm{N}-\mathrm{NH}_{3} / \mathrm{NT}^{2}$ & 25 & 25 & 25 & 25 & 25 & 25 & 25 \\
\hline Acetic acid & -5 & 0 & 0 & -5 & -5 & 0 & 0 \\
\hline Butyric acid & 50 & 50 & 50 & 50 & 50 & 50 & 40 \\
\hline Score & 95 & 100 & 100 & 95 & 95 & 100 & 90 \\
\hline Classification & & & & Excellent & & & \\
\hline
\end{tabular}

Table 4. Chemical composition and in vitro DM digestibility for sorghum BRS-610 silage produced in seven stages of grain maturity

\begin{tabular}{lcccccccc} 
Variable & \multicolumn{9}{c}{ grain maturity stage } & D \\
\cline { 2 - 7 } & Milky & Milky/Dough & Dough & Dough/Dent & Dent & Hard & Dry & CV \\
\hline CP & $7.27 \mathrm{a}$ & $6.93 \mathrm{a}$ & $6.86 \mathrm{a}$ & $6.24 \mathrm{~b}$ & $5.99 \mathrm{~b}$ & $6.77 \mathrm{a}$ & $6.27 \mathrm{a}$ & 5.84 \\
$\mathrm{NDF}$ & $58.85 \mathrm{a}$ & $53.88 \mathrm{~b}$ & $54.66 \mathrm{~b}$ & $53.14 \mathrm{~b}$ & $58.20 \mathrm{a}$ & $61.19 \mathrm{a}$ & $58.43 \mathrm{a}$ & 6.59 \\
$\mathrm{ADF}$ & $33.56 \mathrm{a}$ & $30.57 \mathrm{~b}$ & $31.13 \mathrm{~b}$ & $30.40 \mathrm{~b}$ & $33.22 \mathrm{a}$ & $35.89 \mathrm{a}$ & $35.05 \mathrm{~b}$ & 7.21 \\
Hemicelluloses & $25.29 \mathrm{a}$ & $23.31 \mathrm{~b}$ & $23.54 \mathrm{~b}$ & $22.74 \mathrm{~b}$ & $24.97 \mathrm{a}$ & $25.31 \mathrm{a}$ & $23.70 \mathrm{a}$ & 5.40 \\
Cellulose & 28.35 & 25.15 & 25.95 & 24.16 & 27.22 & 29.75 & 27.01 & 8.38 \\
Lignin & $5.21 \mathrm{~b}$ & $5.42 \mathrm{~b}$ & $5.18 \mathrm{~b}$ & $6.24 \mathrm{~b}$ & $6.00 \mathrm{~b}$ & $6.00 \mathrm{~b}$ & $7.72 \mathrm{a}$ & 13.00 \\
IVDMD & $60.52 \mathrm{a}$ & $60.13 \mathrm{a}$ & $59.77 \mathrm{a}$ & $53.05 \mathrm{~b}$ & $50.57 \mathrm{~b}$ & $45.05 \mathrm{c}$ & $49.75 \mathrm{~b}$ & 4.85 \\
\hline
\end{tabular}

Means within a row without a common letter differ $(\mathrm{P}<0.05)$ by Scott-Knott test. CP: Crude protein. NDF: Neutral detergent fiber. ADF: Acid detergent fiber. IVDMD: in vitro DM digestibility.

The levels of NDF, ADF and hemicelluloses presented similar trends and showed reductions between the milky/dough and dough/dent stages. The highest values for NDF, ADF and hemicelluloses observed in the milky stage may be associated to the low participation of the panicle. On the other hand, in the more advanced stages the increase in levels for these fractions in the leaf and stalk may have suppressed the effect of the higher participation of the panicle in the plant (Faria Jr., 2008).

Pires et al. (2006) observed reduction in the fractions of NDF and ADF with the advancement of the stage of maturity due to the increase in the panicle in the sorghum plant. On the other hand, alterations in the fractions of NDF, ADF and lignin between the milky and hard grain stage of maturity in sorghum silages were not observed by Araújo et al. (2007). Results in the literature for sorghum silage, ensiled in the milky to dough stages indicate values for NDF and ADF ranging from $44.6 \%$ and $63.6 \%$ and $20.2 \%$ to $31.3 \%$, respectively. Based on the results obtained for BRS-610 it is possible to infer that it presents good quality in the fibrous fraction, displaying fiber levels close to those reported for grain sorghums or double purpose sorghums. Regression analysis did not indicate a model that was adequate to the variables NDF, ADF, hemicelluloses and cellulose, showing low $\mathrm{R}^{2}$ values and no significance.

Cellulose and lignin levels were not altered $(\mathrm{P}<0.05)$ by the stage of maturity except by the increase in lignin in the dry grain stage. However, regression analysis indicated increases $(\mathrm{P}<0.01)$ of 0.3 units in lignin levels at each grain maturity stage (Figure 2). Alterations in lignin levels with the advancement of stage of maturity were not observed by Araújo et al. (2007). 


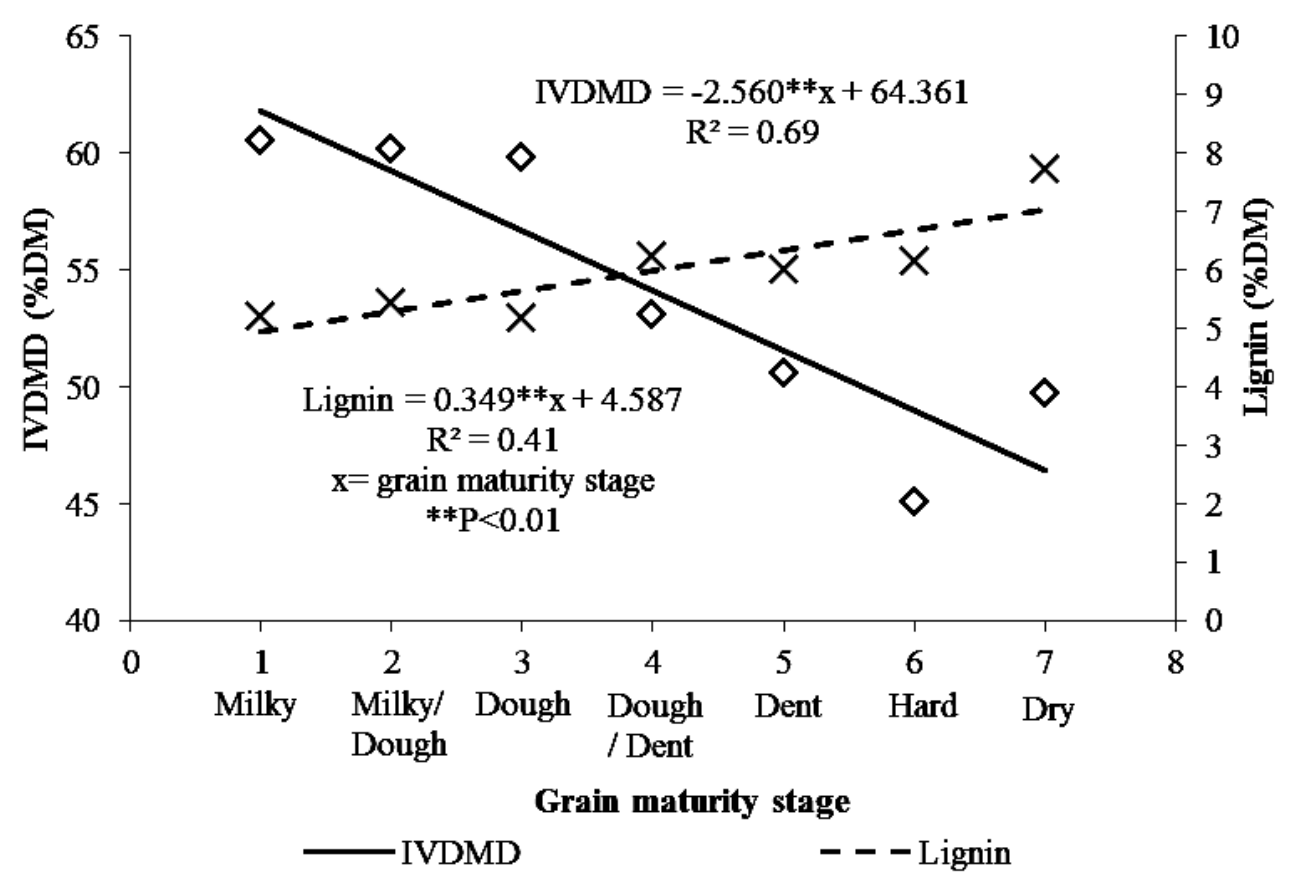

Figure 2. Tendency curves for the estimated values of in vitro DM digestibility (IVDMD) and lignin for silages of sorghum BRS-610 in seven stages of grain maturity. 1-milky; 2-milky/dough; 3-dough; 4dough/dent; 5-dent; 6-hard; 7-dry; with one week intervals between stages, starting from flowering (0).

Pires et al. (2006) however, observed differences in the values for lignin between the hybrids related to the advancement in the stages of maturity. One hybrid presented an increase; another presented a decrease, while there were no alterations for this parameter in a third one. These authors reported lignin values ranging from $4.0 \%$ to $6.0 \%$. However, even if the concentration of lignin does not alter its composition and the hydroxybenzaldehyde compounds ratio, vanillin and syringaldehyde may alter with the advancement of the stage of maturity (Noguera, 2002). According to Saliba et al. (1999), vanillin, which is derived from ferulic acid, is largely responsible for the bonds between lignin and hemicelluloses and for the reduction of the digestibility of forages.

The IVDMD levels were higher and similar among themselves in the early stage of maturity (milky to dough), with reduction for last stages (Table 4). However, regression analysis indicated increases $(\mathrm{P}<0.01)$ of 2.6 units in IVDMD at each grain maturity stage (Figure 2).
No effect of the maturity stage over IVDMD for the sorghum silages evaluated was found by Pires et al. (2006) and Araújo et al. (2007), with averages ranging from $54.9 \%$ to $57.8 \%$ and $47.2 \%$ to $52.2 \%$, respectively. However, higher levels of IVDMD were observed by Silva et al. (1999) with the increase in the proportion of panicle in the ensiled mass. The effect of maturity stage over digestibility is variable in different materials due to the variation in the proportion of parts of the stalk, leaf and panicle in the plant and by the differences between the nutritional values of these fractions, which interferes in the final quality of sorghum silages. Based on the IVDMD values silages can be classified as good to average quality, according to Borges et al. (1997).

In the milky/dough to dough stages good nutritional values were observed, indicated by the lowest levels of fibrous fractions, good levels of digestibility and levels of dry matter which generally do not limit dry matter consumption by ruminants. 


\section{CONCLUSIONS}

The grain maturity stage influenced both the quality of fermentation and the nutritional value of sorghum BRS-610 silages. Results from this experiment indicate that ensilage from sorghum BRS-610, between the milky/dough and dough stages, ensure the silage's high quality fermentation and good nutritional value.

\section{REFERENCES}

ARAÚJO, V.L.; RODRIGUEZ, N.M.; GONÇALVES, L.C. et al. Qualidade das silagens de três híbridos de sorgo ensilados em cinco diferentes estádios de maturação. Arq. Bras. Med. Vet. Zootec., v.59, p.168-174, 2007.

BERNARDINO, M.L.A.; RODRIGUEZ, N.M.; SANTANA, A.A.C. et al. Silagem de sorgo de porte médio com diferentes teores de tanino e suculência no colmo. I. Nitrogênio amoniacal, pH e perdas de matéria seca. Arq. Bras. Med. Vet. Zootec. v.49, p.213-223, 1997.

BORGES, A.L.C.C.; GONÇALVES, L.C.; RODRIGUEZ, N.M. et al. Qualidade de silagens de híbridos de sorgo de porte alto, com diferentes teores de tanino e umidade no colmo. Arq. Bras. Med. Vet. Zootec., v.49, p.441-452, 1997.

BRITO, A.F.; GONÇALVES, L.C. ; RODRIGUES, J.A.S. et al. Avaliação da silagem de sete genótipos de sorgo (Sorghum bicolor (L.) Moench). II. Padrão de Fermentação. Arq. Bras. Med. Vet. Zootec., v.52, p.491-497. 2000.

FARIA Jr., W.G. Avaliação agronômica $e$ nutricional do híbrido de sorgo BRS-610 [Sorghum bicolor (L.) Moench] e de suas silagens em oito idades de corte. 2008. 102f. Dissertação (Mestrado em Zootecnia) - Escola de Veterinária, Universidade Federal de Minas Gerais, Belo Horizonte.

HOLDEN, L.A. Comparison of methods of in vitro dry matter digestibility for ten feeds. $J$. Dairy Sci., v.82, p.1791-1794, 1999.

McDONALD, P.; HENDERSON, A. R.; HERON, S. The biochemistry of silage. 2nd ed. Marlow: Chalcombe, 1991. 340p.
MERTENS, D.R. Gravimetric determination of amylase-treated neutral detergent fiber in feeds with refluxing in beakers or crucibles: collaborative study. J. Assoc. Off.Anal. Chem. Int., v.85, p.1217-1240, 2002.

MOISIO, T.; HEIKONEN, M. Lactic acid fermentation in silage preserved with formic acid. Anim. Feed Sci. Technol., v.47, p.107-124, 1994.

MOLINA, L.R.; GONÇALVES, L.C.; RODRIGUEZ, N.M. et al. Qualidade das silagens de seis genótipos de sorgo (Sorghum bicolor (L.) Moench) em diferentes estádios de maturação. Arq. Bras. Med. Vet. Zootec., v.54, p.159-168, 2002.

NOGUERA, J.R.R. Estudo químico in situ, in vitro e microscópico da parede celular de cinco genótipos de sorgo colhidos em três épocas de corte. 2002. 177f. Tese (Doutorado em Ciência Animal) - Escola de Veterinária, Universidade Federal de Minas Gerais, Belo Horizonte.

OFFICIAL methods of analysis of AOAC international. 17nd ed. Gaithersburg: AOAC International, 2000. 2200p.

PIRES, D.A.A.; GUIMARÃES Jr., R.; JAYME, D.G. et al. Qualidade e valor nutritivo das silagens de três híbridos de sorgo (Sorghum bicolor L.) colhidos em diferentes estádios de maturação. Rev. Bras. Milho Sorgo, v.5, p.241256, 2006.

ROCHA Jr., V.R.; GONÇALVES, L.C.; RODRIGUES, J.A.S. et al. Avaliação de sete genótipos de sorgo (Sorghum bicolor (L.) Moench) para produção de silagem. II - Padrão de fermentação. Arq. Bras. Med. Vet. Zootec., v.52, p.512-520, 2000.

RODRIGUES, J.A.S.; SANTOS, F.G.; SHAFFERT, R.E. et al. BRS 610 - híbrido de sorgo forrageiro para produção de silagem de alta qualidade. (Embrapa Milho e Sorgo, Comunicado técnico 102). 2004. Disponível em: <http://www.cnpms.embrapa.br/publicacoes/publ ica/Comunicado102c.pdf $>$. Acessado em: 10 nov. 2009.

SISTEMA para Análises Estatísticas, Versão 9.1. Viçosa, MG: UFV, 2007. 
Effect of grain maturity...

SALIBA, E.O.S.; RODRIGUEZ, N.M.; GONÇALVES, L.C. et al. Estudo comparativo da lignina isolada da palha de milho com outros indicadores em ensaio de digestibilidade aparente. In: REUNIÃO ANUAL DA SOCIEDADE BRASILEIRA DE ZOOTECNIA, 36., 1999, Porto Alegre, RS. Anais... SBZ: Porto Alegre, 1999.

SILVA, F.F.; GONÇALVES, L.C.; RODRIGUES, J.A.S. et al. Qualidade de silagens de híbridos de sorgo (Sorghum bicolor (L.) Moench) de portes baixo, médio e alto com diferentes proporções de colmo+ folha/panícula 1. Avaliação do processo fermentativo. Rev. Bras. Zootec., v.28, p.14-20, 1999.
TOMICH, T.R.; PEREIRA, L.G.R.; GONÇALVES, L.C. et al., Características químicas para avaliação do processo fermentativo de silagens: uma proposta para qualificação da fermentação. (Documentos 57/Embrapa Pantanal), 2003, 20p, Disponível em :

<http://www.cpap.embrapa.br/publicacoes/online /DOC57.pdf >. Acessado em: 10 nov. 2009.

VAN SOEST, P.J.; ROBERTSON, J.B.; LEWIS, B.A. Methods for dietary fiber, neutral detergent, and nonstarch polysaccharides in relation to animal nutrition. J. Dairy Sci., v.74, p.35833597, 1991. 